\title{
Development of an Integrated Inquiry Model the Value of Thought Economy of Mohammad Hatta in Social Studies Subject
}

\author{
Bangun Hutama Winata ${ }^{1}$, Sunardi $^{2}$, Djono $^{3}$ \\ ${ }^{1,2,3}$ Sebelas Maret University, Surakarta, Indonesia. \\ bangunhutamawinata@gmail.com
}

\begin{abstract}
This study aims to develop inquiry models in social studies learning by integrating the values of Mohammad Hatta's democratic economic thinking in junior high schools in Lampung. The method used in this research is the development research $(R \& D)$ method. The subjects in this study consisted of material validators, model validators, and 48 junior high school students. The results of this development research show that the inquiry learning model integrated with the value of Mohammad Hatta's populist economic thought proved to be valid based on the assessment of the model expert and material expert. Based on the results of small group trials, limited trials and large group trials shows that the integrated inquiry learning model with the economic thought value of Mohammad Hatta proved to be effective and in accordance with needs analysis.
\end{abstract}

\author{
Keywords \\ Development, Inquiry \\ Learning Model, \\ Mohammad Hatta
}

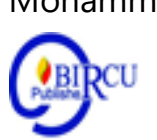

\section{Introduction}

The role of education is very important to create an intelligent, peaceful, open and democratic society, therefore, education reform must always be done to improve the quality of education of a nation. Studying social studies is basically to develop students' knowledge, values, attitudes, and social skills to be able to examine the social life that they face every day with the aim that students are able to develop knowledge, values, and attitudes, and social skills that are useful for them. Social studies education itself has a role to help students become useful and effective members of society, decision making by helping students develop thinking skills and academic skills; help students mark and develop and assess themselves in relation to the lives of the surrounding community; and help students become good citizens (Isjoni, 2007: 34). Social studies can be interpreted by reviewers or studies of the community, teachers can conduct studies from various social perspectives, such as teaching history, economics, geography, sociology, anthropology, government politics, and aspects of social psychology that are simplified to achieve learning goals (Tanwif, 2009: 1-9).

Sapriya in Kiky (2017) said that the model in social studies education is good to use is inquiry. Inquiry is a learning activity that fosters the ability of students to use process skills that are characterized by formulating hypotheses, conducting experiments, collecting and processing data, evaluating and communicating the findings. The implementation of social studies learning models in SMP N 2 Desa is basically in accordance with the RPP, syllabus, and curriculum. But sometimes continuous learning without variations in learning will become boring.

M. Rahmattullah (2011) in his research stated that students often did not pay attention to the learning process because the process of social studies material was considered boring and not pleasant. Based on the results of researchers' interviews with social studies subject teachers, students look bored with the existing subject matter and sometimes even sleepy. So researchers want to develop a learning model that is slightly different but does not deviate 
from the RPP and syllabus so that students are interested in learning social studies material. The results of interviews with students said that they agreed if the learning was integrated with one of the founders of the nation, according to them the learning would seem to be more interesting and also increase understanding of one of the founding fathers of the nation.

Floating inquiry learning models integrated with the values of Mohammad Hatta's democratic economic thinking is expected to become a source of new material that is additional for students, besides that student can also emulate Mohammad Hatta as one of the founders of the nation.

The material used in the development of inquiry learning models is in accordance with basic competencies regarding analyzing the concept of interaction between humans and space so as to produce various economic activities and interactions between spaces for the survival of economic, social and cultural life in Indonesia with the material the role of economics in the economy. Then integrated with the values of popular economic thought of Mohammad Hatta.

\section{Review of Literature}

Learning is the process of changing behavior due to interactions among individuals and the environment. Changes in behavior include changes in knowledge, understanding, attitudes, skills, motivation, interests, thinking abilities and so on. Suparman in Sitorus (2019), argues that "learning is a process of behavior change that can be observed by others including by teachers". Dwidayani in Sitorus (2019) states that, "Learning outcomes are measures of success or failure of students after taking teaching and learning activities both in terms of effective, psychomotor, and cognitive which includes knowledge (memory, understanding, application (application)". Learning outcomes are a form of achievement students as well as a symbol of the success of educators in teaches students (Yusuf in Sitorus, 2019).

Inquiry learning model is learning that emphasizes the thinking process of students so that students are able to independently solve the problems of the issue (Sanjaya, 2017: 191) In inquiry-based learning teachers do not have to always provide answers because the main goal in this learning is to encourage students to systematically think critically, logically, and analytically, so students can formulate their own findings with confidence (Gulo, 2008: 11). The inquiry method refers to the theory of constructivism; learning is an active process in which students build new ideas or concepts based on previous experience and knowledge (Andrini, 2016). The inkuri model is one of the methods suggested in the curriculum in 2013, this method is best used in the learning process. Inquiry based learning has several steps including: making orientation, formulating problems, forming hypotheses, collecting data, testing hypotheses, and concluding (Nurdiansyah and erni, 2006: 149-151).

Learning social science emphasizes aspects of knowledge, facts and concepts that are memorized (Karima \& Rahmadani, 2018). Teaching Social Studies is considered to be less interesting, considered trivial, and boring, causing social studies subjects to experience a dilemma. Teaching students through the speaking method is difficult to motivate to be interested in social studies learning. M. Rahmattullah (2011) in his research that students often did not pay attention to the learning process because the social studies material process was considered boring and not pleasant. Learning culture is more marked by rote learning rather than thinking culture, as a result students assume that social studies are rote learning (Agung Eko Purwana, et al., 2009: 1-9). 
Mohammad Hatta's populist economic thinking according to Fadli Zon (2016: 104-107) is a concept of economic politics, in this case Hatta appropriates humans as the axis in economic activities or development is centred on the people. Economic politics meant by Mohammad Hatta was to describe the problems as they should and try to elaborate on the effects that affect the prosperity of the people or people. Mohammad Hatta was born in Bukit Tinggi on August 12, 1902 Mohammad Hatta was also known Bung Hatta was one of the Founding Fathers and an Indonesian republican proclaimer with Sukarno (Anwar Abas, 2010: 1) Mohammad Hatta had the idea that to achieve prosperity in the economy, the economy was not just investigate the law of static law, which is about the issue of value and price, but also about the journey of economic livelihood in history, describing the historical path taken by the community in its development from the past until now (Mohammad Hatta, 2002: 9)

If you look at the path of Indonesia's economic history, it has rich land but Indonesian people live in poverty amidst abundant wealth (Mohammad Hatta, 2015: 170). Besides that, Mohammad Hatta also wants to restore the noble value of mutual cooperation that has been owned by Indonesian society long ago. The results of Mohammad Hatta's democratic economic thinking were outlined in the form of a cooperative that Moahammad Hatta had dreamed of for a long time. Cooperatives are the main way to build a people's economy (Mohammad Hatta, 2015: 151). Popular economic values in cooperatives include: Solidarity, Individuality / self-confidence, honesty, and cooperation.

\section{Research Method}

This research uses research and development methods. Development Design is a scientific way to research, produce, and test the validation of a product produced (Sugiyono, 2014: 30). The focus of this research is on development, namely how to develop a product and how the effectiveness of the products is produced. This study uses the Borg and Gall development research model. The Borg and Gall development research has 10 stages, namely: (1) potential and problems, (2) data collection, (3) product design, (4) design validation, (5) revision design, (6) product testing, ( 7) revisions, (8) large group trials, (9) revisions, and (10) dissemination and reports (Borg and Gall, 1983: 95). To shorten the time of this research, the steps are reduced to three stages, namely (1) introduction, (2) firing, and (3) evaluation.

This research was carried out in one of the junior high schools in Lampung province, precisely in the Second Senior High School 2 Sekampung or SMP N 2 Sekampung East Lampung Regency. The results of the data obtained from this research consist of qualitative data and quantitative data, for the sake of this research the development model of integrated learning research with the value of Mohammad Hatta's people's economic thinking, the development steps are reduced to three steps, namely: preliminary study stage, learning model development stage, and the stage of model effectiveness through experimentation. The preliminary stage is carried out to obtain qualitative data namely; (1) Analysis; (2) Literature and field studies, this stage is to analyze needs, analyze school curricula, identify learning, describe the results of the analysis. At the development stage carried out to obtain quantitative data consisting of: (1) preparation of a draft learning model to determine core competency, basic competency, and indicators; (2) initial product and validation, at this stage it is carried out to make a list of learning models, then product validation, and the first revision; (3) product trials aim to develop a learning model which is then trialled on a small scale then a second revision is made, and a large scale trial is then conducted a third revision. 
In the evaluation phase, the effectiveness test is carried out in the experimental class and the control class, then the final product is developed.

The analysis technique used in this study is a descriptive statistical analysis technique, to process data from the instrument in the form of an average questionnaire score with the following formula:

Table 1. Guidelines for conversion evaluation criteria

\begin{tabular}{lcl} 
Interval & Score & Criteria \\
\hline $\mathrm{X} \leq 4,21$ & 5 & Exellent \\
\hline $3.40<\mathrm{X} \leq 4.21$ & 4 & Good \\
\hline $2.60<\mathrm{X} \leq 3.40$ & 3 & Enough \\
\hline $1.79<\mathrm{X} 2.60$ & 2 & low \\
\hline $\mathrm{X} \leq 1.79$ & 1 & Fair \\
\hline
\end{tabular}

\section{Discussion}

\subsection{Preliminary Stage}

The preliminary study was carried out at the beginning in October 2019. The purpose of this study was to gather all information about the social studies learning model applied in SMP N 2 Sekampung. Things that must be considered in preliminary research are social studies learning methods that are applied in class and material delivered to students. Discussion of the results of the preliminary study, namely: (1) Analysis, needs analysis is done to determine the needs of teachers and students of the model developed; (2) Literature Review, a literature review collects data sources, examines relevant research related to the research of Mohammad Hatta's populist economic thought, (3) Field Studies conducted at SMP N 2 Sekampung aiming to collect learning data in schools the said; (4) Data collection techniques in this study by conducting interviews with social studies teachers and students, conducting observations or direct observations of social studies learning activities in class, and documentation that is collecting syllabus, learning plans, learning unit, aims to see whether the value of thought material Mohammad Hatta's popular economy can be included in the learning process in accordance with core competencies and basic competencies.

\subsection{Model Development}

At the development stage of the learning model, the researcher designs the model to be developed. Models that are still in the form of initial concepts in the form of learning syntax are validated by experts and tested through limited testing. After doing a series of trials and making improvements.

In the validation phase aims to find out the product criteria that will be developed based on the assessment of these experts. These experts have competencies in their respective fields. The following are the results of an expert's evaluation of the product being developed.

Table 1. Results of the Inquiry Learning Model Assessment

\begin{tabular}{llcl}
\hline No. & Assessment Aspects & $\begin{array}{l}\text { Average } \\
\text { Score }\end{array}$ & Category \\
\hline 1. & Supporting Theory & 4.8 & Exellent \\
\hline 2. & Syntax & 5 & Exellent \\
\hline 3. & Social system & 5 & Exellent \\
\hline 4. & Raction Principle & 4.7 & Exellent \\
\hline 5. & Supporting System & 4.3 & Exellent \\
\hline
\end{tabular}




\begin{tabular}{llcl}
\hline $6 . \quad \begin{array}{l}\text { Learning Impact and } \\
\text { Accompaniment Impact }\end{array}$ & 4.5 & Exellent \\
\hline $7 . \quad$ Learning Implementation & 5 & Exellent \\
\hline Total number & 4.7 & \\
\hline
\end{tabular}

The table above obtained the results of expert model validation scores on the support theory aspect with an average score of 4.8 (very good), syntax aspects get an average score of 5 (very good), aspects of the social system get an average score of 5 (very good), aspects of the principle of reaction get an average score of 4.7 (very good), aspects of the average supporting system 4.3 (very good), aspects of the learning impact and the impact of the scoring average of 4.5 (very good), implementation of learning (very good). Based on the results of the model validation score by the experts as a whole showed that it was very good and worth trying out at a later stage.

Table 2. Results of the RPP Assessment (Learning Implementation Plan)

\begin{tabular}{rlcl}
\hline No. & Assessment Aspects & $\begin{array}{l}\text { Average } \\
\text { Score }\end{array}$ & Category \\
\hline 1. & Subject Identity & 5 & Exellent \\
\hline 2. & Formulation of Indicators & 4.5 & Exellent \\
\hline 3. & Formulation of Learning & 4 & Good \\
& Objectives & & \\
\hline 4. & Selection of Teaching Materials & 4.6 & Exellent \\
\hline 5. & Selection of learning resources & 5 & Exellent \\
\hline 6. & Learning media understanding & 4.7 & Exellent \\
\hline 7. & Learning methods & 4.6 & Exellent \\
\hline 8. & Learning Scenarios & 5 & Exellent \\
\hline 9. & Authentic Assessment Plan & 4.5 & Exellent \\
\hline Total score & 4.6 & Exellent \\
\hline
\end{tabular}

The above table obtained the results of the validation score of the Learning Implementation Plan (RPP) on the aspect of subject identity with an average score of 5 (very good), aspects of the formulation of indicators with an average score of 4.5, aspects of the formulation of learning objectives with an average score of 4 (Good), aspects of the selection of teaching materials with an average score of 4.6 (very good), aspects of the selection of learning resources with an average score of 5 (very good), aspects of understanding learning media with an average score of 4.7 (very good), aspects of learning methods with an average score of 4.6 (very good), aspects of learning scenarios with an average score of 5 (very good), aspects of an authentic assessment plan with an average score of 4.5. as a whole the average score of the model validation is very good and worth testing in the next step.

Table 3. Results of the Evaluation of Material for the Role of Economic Actors in the Economy and the Economic Thought Value of Mohammad Hatta

\begin{tabular}{llcl}
\hline No. & $\begin{array}{l}\text { Assessment } \\
\text { Aspects }\end{array}$ & $\begin{array}{l}\text { Average } \\
\text { Score }\end{array}$ & Category \\
\hline 1. & Format & 4 & Good \\
\hline 2. & Language & 3.6 & Good \\
\hline 3. & Illustration & 4.3 & Exellent \\
\hline 4. & Content & 4 & Good \\
\hline Total score & 3.9 & Good
\end{tabular}


The table above shows the aspect of the format of the average score reached 4 (good), the aspect of the language average score obtained 3.6 (good), aspects of the illustration reached an average score of 4.3 (very good, and the aspect of the contents of the average score reached 3.9 (good), and on the total score aspects of the assessment obtained a score of 3.9 (good) .Based on the results of the assessment the learning material is ready to be used.

\subsection{Test the product}

At the product trial stage to assess the quality of the learning model being developed. Product trials are carried out through 3 stages, namely small group limited trials, large group trials, and extensive trials.

The following is a small group restricted trial to 5 homogeneous VIII grade students, with the following results.

Trials are limited to small groups

\begin{tabular}{llll}
\hline No. & Assessment Aspects & $\begin{array}{l}\text { Average } \\
\text { score }\end{array}$ & Category \\
\hline 1. & Learning model & 3.67 & Good \\
\hline 2. & Learning materials & 3.75 & Good \\
\hline Total score & 3.71 & Good \\
\hline
\end{tabular}

In the table above explains that student responses regarding aspects of the assessment of learning models get a score of 3.67 or can be said (Good), in the assessment aspects of learning materials with a score of 3.75 or can be said (Good), and for the total number of aspects of the assessment gets a score of 3.71 which means it can be categorized (Good). Based on these results that the integrated inquiry learning model of Mohammad Hatta people's economic thought values is included in the good category, while criticisms and suggestions regarding the basic concept of values in Mohammad Hatta people's economic thinking are still poorly understood, for this criticism and suggestions will be used as an improvement for the stage next.

The next stage is a limited coa test with a large scale, in this large group trial using 10 VIII grade students outside the small group trial students who have been given treatment. Following the results of the assessment of large group tests can be seen in the table below.

\begin{tabular}{llll}
\multicolumn{4}{c}{ Limited trials are limited to large groups } \\
\hline No. & Assessment Aspects & $\begin{array}{l}\text { Average } \\
\text { Score }\end{array}$ & Category \\
\hline 1. & Learning model & 4.24 & Exellent \\
\hline 2. & Learning materials & 4.15 & Exellent \\
\hline Total score & 4.2 & Exellent \\
\hline
\end{tabular}

Based on the table above it can be explained that in the aspects of the learning model score 4.24 or can be interpreted (Very Good), in the aspect of learning material aspects get a score of 4.15 or can be interpreted (Very Good), and the total score reaches 4.2 with the category (Very Good) . Based on the results of the following table shows an integrated learning model with the value of popular economic thought into the excellent category based on responses from student evaluators. Improving the delivery of the value of thought and material so that it is more easily understood by students. 
The next stage after the product is revised, then enter the broad test phase. Extensive tests were conducted on 25 students of class VIII outside of the large and small test group students.

The following are the results of the extensive test table.

\section{Extensive trial data}

\begin{tabular}{llll}
\hline No. & Assessment Aspects & $\begin{array}{l}\text { Average } \\
\text { Score }\end{array}$ & Category \\
\hline 1. & Learning model & 4.37 & Exellent \\
\hline 2. & Learning materials & 4.31 & Exellent \\
\hline Total score & 4.3 & Exellent \\
\hline
\end{tabular}

Based on the table above, it can be explained that the aspects of the learning model score 4.37 or can be interpreted (Very Good), the aspects of learning theory get a score of 4.31 or (Very Good), and the total score is 4.3 with the category (Very Good). Based on the results of the table states that the development of inquiry learning model integrated with the value of Mohammad Hatta's popular economic thinking is included in the excellent category based on the assessment of respondents from students.

\subsection{Integrated Inquiry Learning Model with the Economic Thought Value of Mohammad Hatta}

Research into the development of inquiry learning models integrated with the value of Mohammad Hatta's populist economic thought in social studies subjects VIII is very good and is also suitable to be used as a learning model in classroom learning. This learning model is designed and arranged according to the syntax of development research learning.

The development of an integrated inquiry learning model with the economic values of Mohammad Hatta gave rise to new responses to students and teachers. The limitations of the material in textbooks and students' boredom towards methods that are often taught without any variation in teaching make it necessary to develop this learning model. The inquiry learning model that has been integrated with the values of Mohammad Hatta's popular economic thinking can be developed to increase the attractiveness of students to study social studies, by using this learning model and coupled with the integrated values of Mohammad Hatta's popular economic thinking students will be more interested and also add new knowledge about democratic economic thought beyond the subject matter. So it can be said if the teaching method is interesting then the learning process will run smoothly and in the end they consider that social studies is easy and fun to learn and learning models that have been integrated with the values of Mohammad Hatta's people's economic thinking are expected to foster nationalism through one of the nation's figures, besides that it can also emulate the values of thought in the people's economy.

\section{Conclusion}

Through the Research Amd Development method rounded the development of inquiry learning models that are integrated with the values of Mohammad Hatta's populist economic thought in social studies subjects class VIII. Based on observations and observations identified the need for inquiry learning models that are integrated with the values of Mohammad Hatta's popular economic thinking to help teachers and students in the learning process in the classroom. The subject of knowledge discussion is taken from the material 
based on the curriculum, planning of learning tools, and in accordance with the standards of competence and basic competencies that have been set.

Based on the results of the analysis and discussion, it can be concluded that the development of an IPS social learning model with the value of Mohammad Hatta's popular economic thinking is said to be valid and belongs to the very good category. This is based on the validation of material experts, model experts and lesson plans. Likewise on the results of the small group limited trials, large group tests, and extensive tests, included in the category very well, and in accordance with the needs of teachers and students in achieving the percentage of learning objectives.

\section{References}

Abas, A. (2010). Bung Hatta dan Ekonomi Islam. Kompas: Jakarta.

Borg \& Gall. (1983). Education Reseacrh: An Introduction (4th ed). NewYork: Longman Gulo, W.(2008). Strategi Belajar Mengajar. Jakarta: Grasindo.

Hatta, M. (2002). Pengantar ke Jalan Ekonomi Sosiologi. PT. Gunung Agung Tbk: Jakarta.

Hatta, M. (2015). Membangun Koperasi dan Koperasi Membangun Gagasan \& Pemikiran. Pernerbit Buku Kompas: Jakarta.

Isjoni. (2007). Cooperative Learning: Efektifitas Pembelajaran Kelompok. Bandung: Alfabeta.

Karim \& Ramadhani. (2018). Permasalahan Pembelajaran IPS dan Strategi Jitu Pemecahannya. ITTIHAD. Vol 11. No 1. Januari-Juni 2018.

Kiky Chandra Silvia Anggraini. (2017). Penggunaan Model Pembelajaran Inkuiri Terbimbing Dalam Pembelajaran Ips Untuk Meningkatkan Kepekaan Sosial Terhadap Lingkungan Siswa Madrasah Ibtidaiyah di Lamongan. At-Thullab: Jurnal Pendidikan Guru Madrasah Ibtidaiyah. Volume 1 Nomor 1 Tahun 2017

M. Rahmattullah. (2011). Manfaat Media Pembelajaran Film Animasi Terhadap Hasil Belajar. Jurnal UPI Edisi Khusus. No. 1 Agustus 2011

Nurdiansyah \& Eni. (2016). Inovasi Model - Model Pembelajaran Sesuai Kurikulum 2013. Sidoarjo: Nizamia Learning Center.

Purwana, A. E. et al. (2009). Pembelajaran IPS MI. Surabaya: A Print A.

Sanjaya, W. (2017). Perencanaan dan Desain Sistem Pembelajaran. Jakarta: Kencana.

Sitorus, H. (2019). The Effect of Learning Strategy and Thinking Ability on The Students' Learning Outcomes in Economics Subject of XI Social Students in Senior High School State 1 in Pematang Siantar. Budapest International Research and Critics in Linguistics and Education (BirLE) Journal. P. 451-460.

Sugiyono. (2014). Metode Penelitian Kuantitatif Kualitatif dan R\&D. Bandung. Alfabeta.

Tanwifi, et al. (2009). Ilmu Pengetahuan Sosial 1. Surabaya: Lapis PGMI

Vera Septi Andrini. (2016). The Effectiveness of Inquiry Learning Method to Enhance Students Learning Outcome A theoritical and Emperical Review. Journal of Educatiun and Practice. Vol. 7 No. 32016

Zon, F. (2016). Pemikiran Ekonomi Kerakyatan Jalan Politik Kemakmuran Indoensia. Jakarta: Fadli Zon Library. 